\title{
Pulmonalis vénaizoláció elött elvégzett echokardiográfia speciális szempontjai
}

\author{
Nagy László, Jenei Csaba, Csanádi Zoltán \\ Debreceni Egyetem, Általános Orvostudományi Kar, Kardiológiai Tanszék, Debrecen \\ Levelezési cím: Dr. Nagy László, e-mail: nagylaszlo69@gmail.com
}

A pulmonalis vénaizoláció $(\mathrm{PVI})$ egy jól megalapozott terápia az optimális antiaritmiás kezelés mellett is szimptómás pitvarfibrilláló betegekben. A pitvarfibrilláció abláció első leírása óta számos vizsgálat igazolta paroxizmális és perzisztens pitvarfibrilláló betegeknél a katéteres abláció elönyét a sinusritmus fenntartásában a gyógyszeres kezeléssel szemben. Ugyanakkor PVI után a betegek akár 70\%-ánál is jelen van a pitvarfibrilláció rekurrencia. Ebből adódóan az ideális betegek kiválasztása fontos klinikai igény. Azonban a bal pitvari struktúra és funkció, illetve a pitvarfibrilláció előfordulási gyakorisága és a stroke-rizikó közötti komplex kapcsolat nem jól ismert. Ráadásul a pitvari remodelling progressziója még 12 hónap után is kimutatható a nagy gyakorisággal paroxizmálisan és perzisztensen pitvarfibrilláló betegekben. Cikkünk célja, hogy áttekintést adjon a PVI elött elvégzett echokardiográfiás módszerek klinikai alkalmazhatóságáról.

Kulcsszavak: pitvari remodelling, pitvarfibrilláció, echokardiográfiás módszerek, pulmonalis vénaizoláció

Pulmonary vein isolation (PVI) is a well-established therapy in patients with atrial fibrillation who remain symptomatic under optimal medical therapy. Since the original description of atrial fibrillation ablation, numerous studies have demonstrated the superiority of catheter ablation over pharmacological therapy for maintenance of sinus rhythm in patients with both paroxysmal and persistent atrial fibrillation. However, up to $70 \%$ of patients present with recurrence of atrial fibrillation after PVI. Therefore, identifying ideal candidates is an unmet clinical need. Nevertheless, the complex relationship between left atrial structure and function, electrical burden of atrial fibrillation and stroke risk is not well understood. Furthermore, progression of atrial remodeling has been shown to occur even over 12 months in patients with high-burden paroxysmal or persistent AF. The purpose of our article to provide an overview of clinical applicability of echocardiography methods performed before PVI.

Keywords: atrial remodeling, atrial fibrillation, echocardiography methods, pulmonary vein isolation

\section{Bevezetés}

A bal pitvari strukturális remodelling paroxizmális pitvarfibrillációban (pPF) a bal pitvar méretének növekedéséhez vezet. A legújabb, nagyobb betegszámot tartalmazó vizsgálatok eredményei alapján a bal pitvari volumen testfelszínre vonatkoztatott (bal pitvari volumenindex - LAVI) normális felső értéke a korábbi 25 , illetve 28 helyett $34 \mathrm{ml} / \mathrm{m}^{2}$-re változott (1). A férfi nem, a gyakran jelenlévő hipertónia és diasztolés diszfunkció
(DD) szintén a LAVI-t növelő tényezők. A DD jelenléte a pPF független prediktora, de a pPF szerepe a DD kialakulásában nem tisztázott. A $32 \mathrm{ml} / \mathrm{m}^{2}$-t meghaladó LAVI az iszkémiás stroke (2) és a HFpEF (Heart Failure with Preserved Ejection Fraction) kialakulásának (3) független elörejelzője. Megtartott ejekciós frakció (EF) mellett a $40 \mathrm{ml} / \mathrm{m}^{2}$ feletti LAVI $42 \%$-os mortalitás növekedéssel járt (4). A bal pitvari méret és a kardiovaszkuláris események közötti korreláció a bal pitvari volumen 

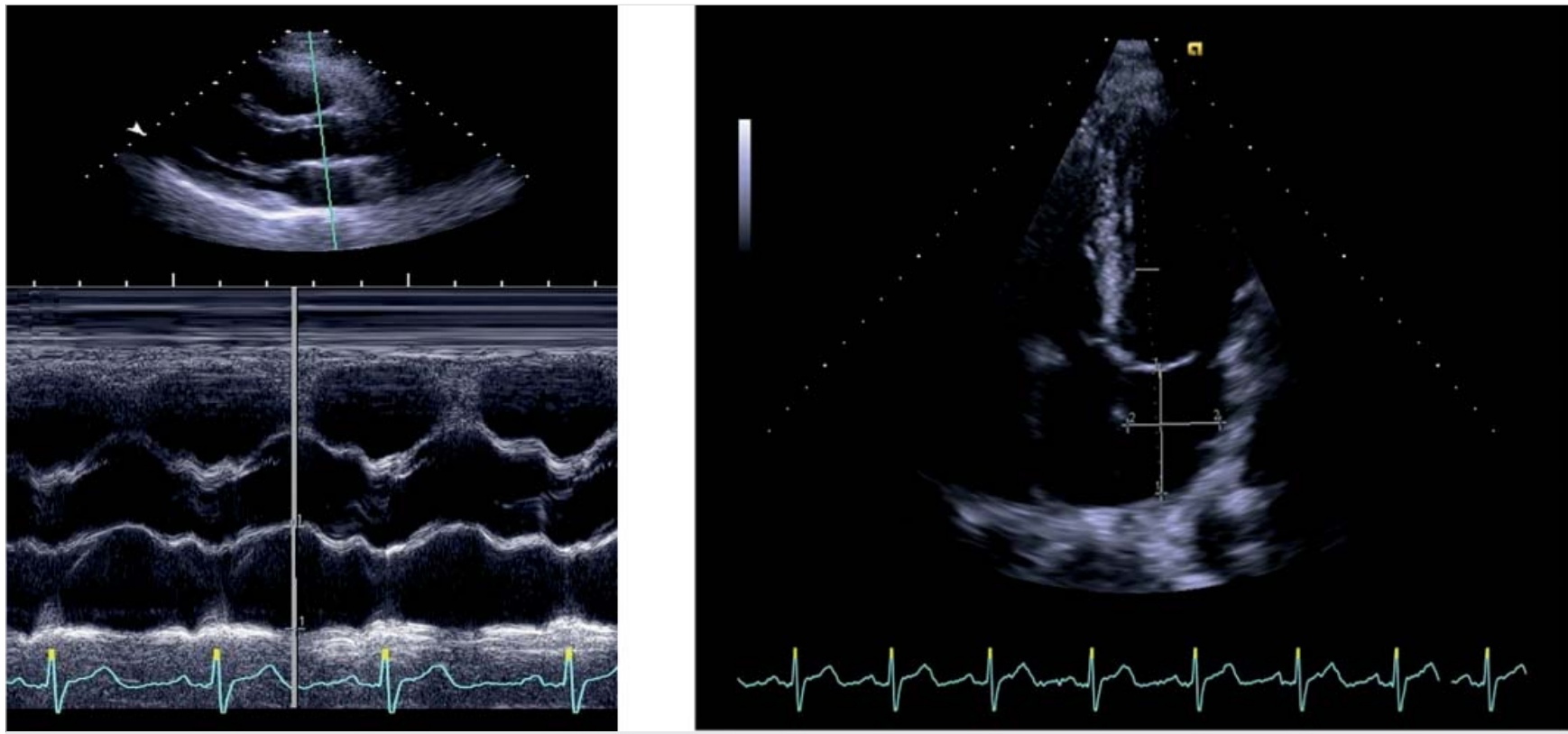

1. ÁBRA. A paraszternális hosszmetszeti M-módból mért bal pitvari antero-poszterior átmérő (balra) és a csúcsi 4 üregi metszetből mért szupero-inferior hossz-, illetve mediolaterális harántátmérő (jobbra)

esetén erősebb, mint a bal pitvari átmérő esetén (5). Bár a bal pitvari méret és funkció, illetve a pitvarfibrilláció gyakorisága közötti kapcsolat sok tekintetben nem tisztázott, számos klinikai tényező mérlegelése mellett a PVI-ra kerülő ideális betegek kiválasztásában a különböző echokardiográfiás metodikáknak döntő szerepe van.

\section{Bal pitvari méret- és volumenmeghatározás}

A valós bal pitvari mérettel a csúcsi 4 üregi metszetből mért szupero-inferior hosszátmérő jobban korrelál, mint a paraszternális hosszmetszetben M-módból mért antero-poszterior átmérő (6). A mellkas visszatartó ereje miatt a bal pitvari növekedés aszimmetrikus és föleg szupero-inferior, illetve medio-laterális irányú (1. ábra). A bal pitvari volumen meghatározására többféle módszer is ismert (2. ábra).

Az ellipszoid módszer a valósnál kisebb volument eredményez (7). A biplane area-lenght (3. ábra) és a biplane Simpson-módszerek hasonló volumeneket mérnek és szoros korrelációt mutatnak a 3 dimenziós transztorakális echokardiográfiás mérésekkel $(8,9)$. Mivel a biplane area-lenght módszernél elméletileg pontosabb és kevesebb geometriai feltételezést tartalmaz, a biplane Simpson-módszer javasolt a LAVI mérésére a klinikai gyakorlatban (1).

A szív MR-mérésekhez viszonyítva a 2D bal pitvari volumenmeghatározáshoz képest a 3D-echokardiográfia pontosabb (10) és kiváló prognosztikai képességgel rendelkezik (11). A legtöbb vizsgálatban a 3D-echokardiográfiás bal pitvari volumenek jellemző- en nagyobbak, mint a 2D-s volumenek $(10,12)$. A fenti előnyök ellenére standardizált módszertan és elégséges klinikai adat hiányában a 3D-echokardiográfia jelenleg nem javasolt a bal pitvari volumen meghatározására (1).

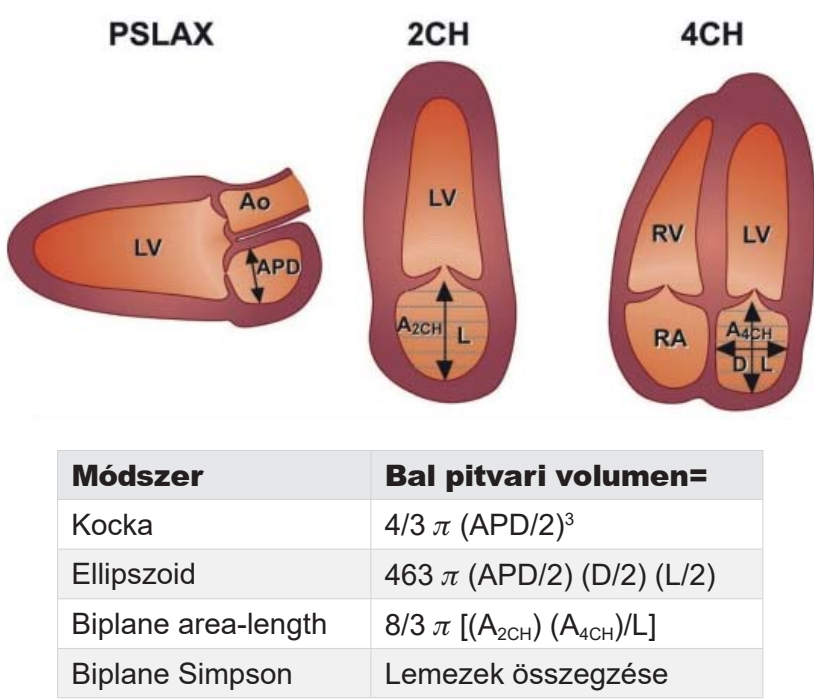

2. ÁBRA. A bal pitvari volumenmeghatározás leggyakoribb módszerei. A méréseket a legnagyobb bal pitvari nyomás és volumen kialakulásakor, a T-hullám végén kell elvégezni. A: area, APD: antero-poszterior átmérő, Ao: aorta, D: bal pitvari harántátmérő, L: bal pitvari hosszátmérő, LA: bal pitvar, LV: bal kamra, PSLAX: paraszternális hosszmetszet, RA: jobb pitvar, RV: jobb kamra, $2 \mathrm{CH}$ : 2 üregi, $4 \mathrm{CH}$ : 4 üregi 


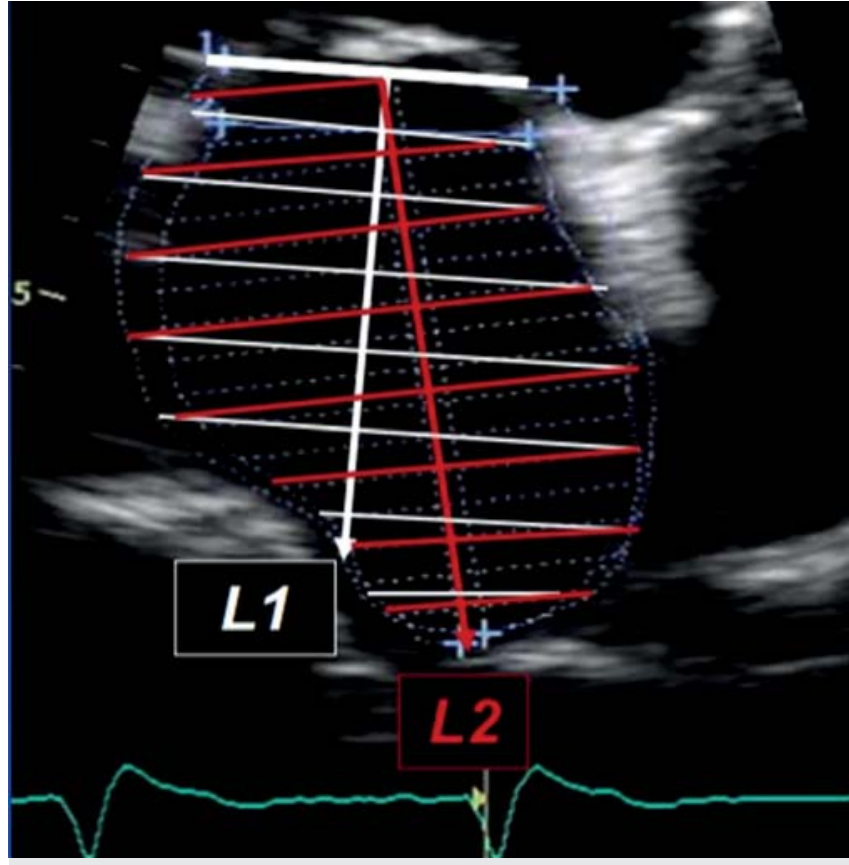

3. ÁBRA. A biplane area-length módszernél a bal pitvari hosszátmérő (L1) mérésekor figyelni kell arra, hogy nem mindig a mitrális annulusra merőleges a legnagyobb pitvari hossz (L2)

\section{Bal pitvari funkcionális remodelling pPF-ben}

A tágabb bal pitvar nem jelent bal pitvari diszfunkciót, azaz a strukturális remodelling nem egyenlő a funkcionális remodellinggel. Adatok vannak arra, hogy a funkcionális károsodás korábban kialakul, mint a bal pitvari méret növekedése (13), ugyanakkor atlétákban a tág pitvarok megtartott funkcióját írták le (14). Több bal pitvari funkcionális paramétert is kórosnak találtak pPFben, de ezekben a tanulmányokban nem vizsgálták a funkcionális és a strukturális remodelling viszonyát.

A bal pitvari dilatációt gyakran fokozott intersticiális fibrózis kíséri, amely hozzájárul a bal pitvari funkció romlásához (15). A mágneses rezonancia képalkotás (MRI) késői gadoliniumhalmozással lehetővé teszi a bal pitvari fibrózis detekcióját és a fibrotikus szövet mennyiségi meghatározását (16). Ez a módszer a preablációs fibrózis meghatározása alapján segít a megfelelő betegek kiválasztásában és a PVI stratégiájának meghatározásában (17).

A bal pitvari funkció ismerete fontos klinikai adat, mert a későbbi kardiovaszkuláris események előrejelzésében hozzájárulhat a LAVI már említett prediktív szerepéhez. A bal pitvari globális pumpafunkciót jellemző csúcs pitvari miokardiális szöveti sebesség (a') a mortalitással és a major kardiális eseményekkel szoros reverz összefüggést mutat (18). A $7 \mathrm{~cm} / \mathrm{s}$-nál kisebb a' esetén a 2 éves kardiális összhalálozási rizikó növekedését találták (19). Az a' sebesség mérése egyszerü, nem költség- és időigényes, ezért hasznos lehet pPF-ben a funkcionális remodelling, illetve PVI után a reverz remodelling követésére.

\section{Bal pitvari volumenek és funkciók}

$A$ bal pitvar esetében $V_{\max }\left(B P V_{\text {max }}\right), V_{\text {min }}\left(B P V_{\text {min }}\right)$ és $V_{\text {preA }}\left(B P V_{\text {preA }}\right)$ volumenekről, illetve rezervoár-, konduit-, és kontraktilis funkcióról beszélhetünk. A kamrai szisztolé alatt zajlik a bal pitvar töltése a mitrális billentyű záródásától annak nyitódásáig. Az ez idő alatt a bal pitvarba kerülő volumen a bal pitvari összürítési volumen, amely a bal pitvari maximális és minimális volumenek különbsége $\left(B P V_{\max }-B P V_{\text {min }}\right)$. Ez a volumen a bal pitvar rezervoár funkcióját jellemzi. A kamrai diasztolé kezdetén a bal pitvari passzív ürítési volumen $\left(B P V_{\max }-\mathrm{BPV}_{\text {preA }}\right)$ kerül a bal kamrába, amely a konduitfunkció következménye. A bal pitvari kontrakció kezdetétől a mitrális billentyű záródásáig a bal pitvari aktív ürítési volumen $\left(B P V_{\text {preA }}-B P V_{\text {min }}\right)$ jellemzi a bal pitvari pumpafunkciót (4. ábra).

A bal pitvar funkciói megítélhetők a klasszikus spektrális Doppler-görbék segítségével. Transztorakális echokardiográfiával (TTE) a bal pitvari funkció vizsgálatához a pulzatilis Doppler-echokardiográfia segítségével rögzített transzmitrális áramlás, illetve a csúcsi 4 üregi metszeten a jobb felső pulmonalis vénában (RSPV) felvett pulmonalis vénás flow Doppler-görbéit tanulmányozhatjuk (5. ábra).

A bal pitvar rezervoárfunkcióját az S-hullám csúcssebessége, VTI-je, valamint a PV Doppler-görbe szisztolés frakciója (PVSF) jellemzi. A PVSF $=\mathrm{VTI} I_{S} / V T I_{S+D}$. A konduitfunkcióra a $D$-hullám csúcssebességéből és VTI-jéből következtethetünk. A bal pitvari pumpafunkciót az A-, illetve a PVAR-hullám csúcssebessége és VTI-je egyaránt jól jellemzi. Ezt a funkciót a bal pitvari

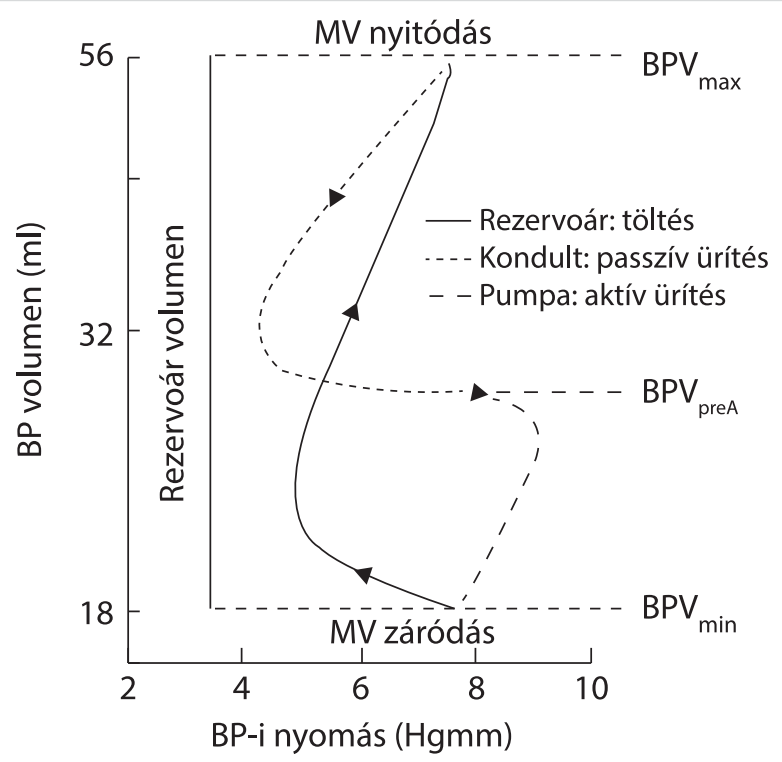

4. ÁBRA. Bal pitvari nyomás-volumen görbe a bal pitvari funkciókkal és az azokhoz tartozó volumenekkel. BP: bal pitvar, MV: mitrális billentyű, preA: bal pitvari kontrakció kezdete (Blume GG, et al. nyomán) (20) 

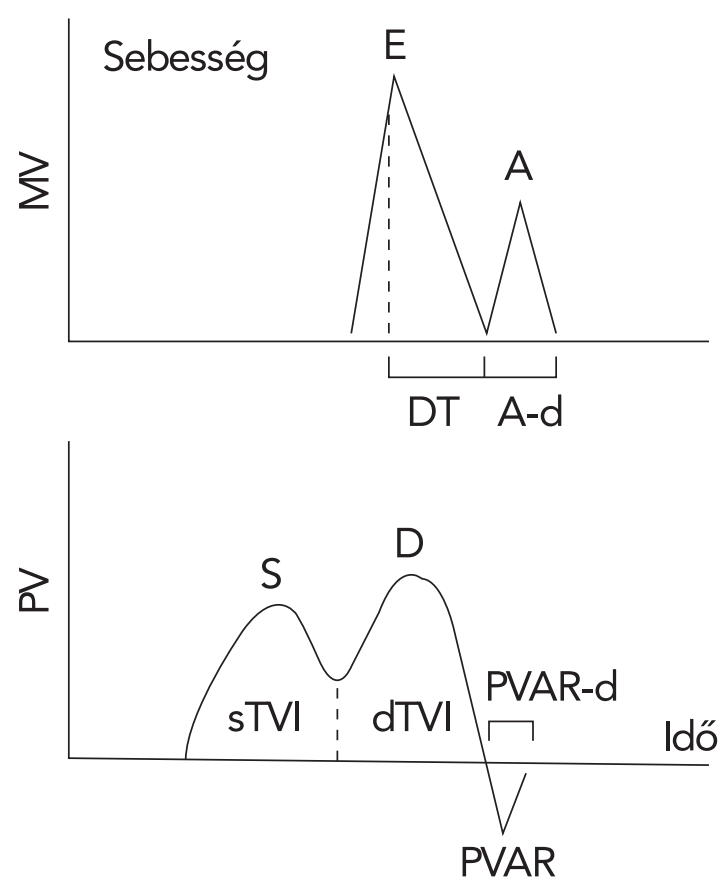

5. ÁBRA. Sinusritmusban a kilégzés végén felvett mitrális beáramlási (felső) és pulmonalis vénás Doppler (alsó) görbék sebesség-idő integráljai (velocity-time integral-VTI) szisztoléban (s) és diasztoléban (d). A-d: pitvari kontrakció időtartama, DT: decelerációs idő, MV: mitrális billentyű, PV: pulmonalis véna, PVAR: pitvari reverz áramlás a PV-ben pitvari kontrakció alatt, PVAR-d: pitvari reverz áramlás időtartama

telődési frakció (BPTF= $\left.V T I_{A} / V T I_{E+A}\right)$ alapján is meghatározhatjuk.

2D biplane metodikákkal vagy 3D-mérésekkel nyert volumenek felhasználásával a bal pitvar funkcióit vo- lumetrikusan is meghatározhatjuk, amely pontosabb, mint a lineáris mérések (21). Azonban az MRI-vel meghatározott értékekhez képest az echokardiográfiás bal pitvari volumen-meghatározás hajlamos a volumeneket alábecsülni (22). A klinikai gyakorlatban a volumetrikus bal pitvari funkció meghatározására, egyszerüsége, költséghatékonysága és non-invazivitása miatt a 2D biplane módszereket alkalmazzuk. A 3D pitvari volumenmérések jól korrelálnak a 2D biplane meghatározásokkal, ugyanakkor járulékos diagnosztikus vagy prognosztikus információt nem nyújtanak (9).

\section{Bal pitvari strain meghatározás}

A bal pitvari funkció meghatározására újabban a bal pitvari speckle tracking echokardiográfia (2D vagy $3 D$ ) alkalmazása és a bal pitvari strain meghatározása került előtérbe (23). Ezzel a módszerrel a bal pitvari funkció minden fázisa jellemezhető, és a bal pitvari strain meghatározásának a különböző kóros állapotokban prognosztikai jelentősége is van (24). Az így meghatározott eredmények közvetlenül nem hasonlíthatók öszsze a volumetrikusan nyert adatokkal (25). A bal pitvari strain mérésével korán detektálható a bal pitvari diszfunkció, emellett új patofiziológiai ismeretekkel szolgálhat, és talán segíthet irányítani az adott kórkép kezelését is (6. ábra).

A pitvarfibrillációban történő képalkotásban a bal pitvari strain meghatározásának klinikai jelentőségét a legújabb European Association of Cardiovascular Imaging (EACVI) ajánlás is hangsúlyozza (26). A bal pitvari strain a pitvarfibrilláció előfordulásának és rekurrenciájának a prediktora, és úgy tủnik, hogy tromboembóliás rizikóval is társul (27). Az iszkémiás stroke szempont-

A: Bal pitvari strain (\%)

B: Bal pitvari strain rate $\left(\mathrm{s}^{-1}\right)$

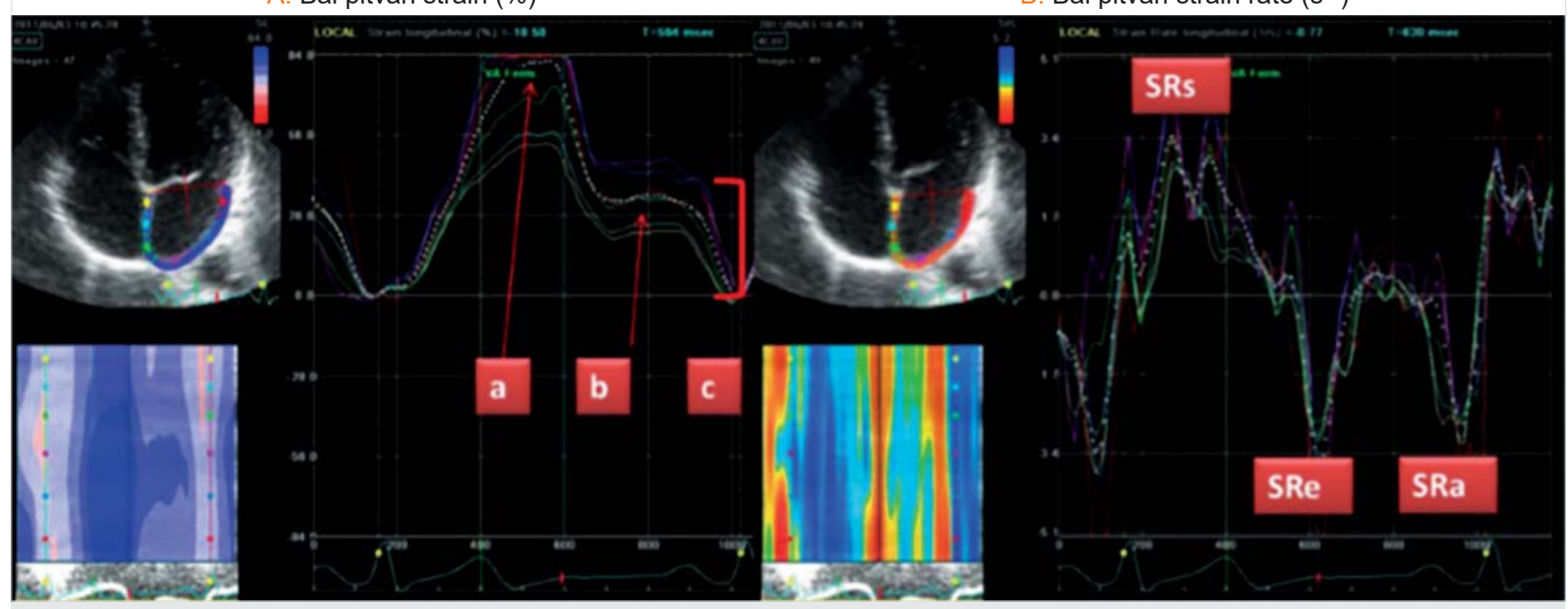

6. ÁBRA. A: Jellegzetes bal pitvari strainfelvétel; a: rezervoár, b: konduit, c: pumpafunkció. B: Ugyanannak a betegnek a strain rate görbéi. Mivel a vér bal kamrai beáramlása a bal pitvari miokardiális rostok rövidülésével kísért folyamat, ezért a SRe és SRa értékek negatívak. Egészségesekben a rezervoárfunkció 40, a konduitfunkció 35 és a pumpafunkció $25 \%$-ban járul hozzá a bal kamrai stroke-volumenhez. SR: strain rate (Donal E, et al. nyomán) (25) 
jából a $\mathrm{CHA}_{2} \mathrm{DS}_{2}-\mathrm{VASc}$ score alapján alacsony rizikójú pitvarfibrilláló betegeknél a bal pitvari rezervoár strain meghatározása egy további rizikóstratifikációt tesz lehetővé, amely segítheti az antikoaguláns kezelés elindítását (28). A bal pitvari strain ismerete fontos szerepet játszik a DD súlyosságának meghatározásában is (29). A HFpEF bizonyos fenotípusainak jellemzésére a bal pitvari strain fontos klinikai paraméter és prognosztikai jelentőséggel is bír (30).

Amennyiben a bal pitvari strain a mindennapi klinikai gyakorlatban elfogadottá válik a bal pitvari funkció meghatározására, akkor a standardizált módszertant, az egységes referenciaértékeket, valamint a különböző betegségek bal pitvari funkcióra gyakorolt hatását pontosan meg kell határozni (31).

\section{Bal pitvari fülcsefunkció és thrombus pPF-ben}

A pPF miatt legalább 3 hetes terápiás orális antikoaguláns kezelés mellett PVI-re kerülö betegeknél 1,62,0\%-ban van jelen bal pitvari fülcsethrombus (32). A pitvarfibrilláció ablációs konszenzus dokumentum alapján a szakértők $50 \%$-a minden betegnél transoesophagealis echokardiográfiát (TEE) végzett $\mathrm{PVI}$ elött (33). A SPAF III-vizsgálat (The Stroke Prevention in Atrial Fibrillation III) egyik alvizsgálatában 382 magas tromboembóliás rizikójú pitvarfibrilláló betegben azt találták, hogy $20 \mathrm{~cm} / \mathrm{s}$ alatti ürítési fülcse flow csúcssebesség esetén a bal pitvari fülcsethrombus gyakorisága több, mint 3 -szor (17 versus $5 \%$ ) és az iszkémiás stroke rizikója 2,6-szor nagyobb volt, mint magasabb sebességek esetén $(34,35)$. Több, kisebb esetszámú tanulmány is felvetette a TEE-vel meghatározott ürítési bal pitvari fülcse flow csúcssebessége és a bal pitvari globális pumpafunkciót jellemző a', illetve a rezervoárfunkciót tükröző bal pitvari összürítési frakció $\left(B P V_{\max }-B P V_{\min } / B P V_{\max }\right)$ közötti pozitív korrelációt, de ezek megerősítésére további vizsgálatok szükségesek $(36,37,38)$.

A jelenlegi klinikai gyakorlatban nincs egységes álláspont arra vonatkozóan, hogy vajon minden PVI-re kerülö betegnél elvégezzük-e a TEE-vizsgálatot a bal pitvari fülcsethrombus kizárására. Számos klinikai tényező $\left(\mathrm{CHA}_{2} \mathrm{DS}_{2}\right.$-VASc score, ingadozó INR melletti orális antikoaguláns [OAC], illetve direkt OAC [DOAC] alkalmazás, aktuálisan zajló vagy perzisztens pitvarfibrilláció) egyénre szabott mérlegelése alapján érdemes dönteni a TEE-vizsgálat szükségességéröl. A döntést az is befolyásolhatja, hogy a PVI alatt alkalmazásra kerül-e a transseptalis punkció vezérléséhez intrakardiális echokardiográfia (ICE). A TEE alatt észlelt bal pitvari spontán echokontraszt, illetve a fülcsére vonatkozó kétes leletek esetén az ICE használatával nagyobb valószínűséggel diagnosztizálhatjuk a bal pitvari fülcsethrombus jelenlétét, amely potenciálisan kimozdulhat a katéteres manipuláció alatt $(39,40)$.

\section{Aszimptómás DD és a pitvarfibrilláció kapcsolata}

Pitvarfibrillációban az aszimptómás DD előfordulási gyakoriságáról nincs megbízható irodalmi adat, de több vizsgálatban is az emelkedett bal kamrai töltőnyomás becslésére használt E/e' hányados (e': koradiasztolés miokardiális sebesség) növekedését találták. A CHARM-vizsgálat echokardiográfiai alcsoportelemzésében (CHARMES) kimutatták, hogy megtartott ejekciós frakciójú szívelégtelen betegekben a II. fokú DD 3,7-szeresére, a III. fokú DD pedig 5,7-szeresére növeli a kardiovaszkuláris halálozás és a szívelégtelenség miatti hospitalizáció kockázatát (41). Az is ismert, hogy a DD jelenléte a pitvarfibrilláció kialakulásának kortól független prediktora és a rizikó mértéke a DD súlyosságától függ (42). Lone pPF-ben ellentmondásos adatokat közöltek $(43,44)$, más szerzők az e' csökkenését találták $(45)$. Egy körülbelül fele-fele arányban paroxizmális $(n=70)$ és perzisztens $(n=54)$ pitvarfibrilláló beteget tartalmazó vizsgálatban a betegek $16 \%$-ában igazolódott emelkedett töltőnyomással járó (II. vagy III. fokú) DD, míg relaxációs zavart (I. fokú DD) a betegek 21\%-ában írtak le (46).

\section{HFpEF és a pitvarfibrilláció kapcsolata}

Az aszimptómás DD progressziója esetén alakulhatnak ki a szívelégtelenség tünetei megtartott EF (HFpEF) mellett is. A progressziót fokozó faktorok és társbetegségek a hipertónia, diabetes mellitus, iszkémiás szívbetegség, krónikus obstruktív tüdőbetegség, obesitas, anémia, veseelégtelenség és alvási apnoe (47). A progressziót a fentiek mellett a pitvarfibrilláció jelenléte is fokozza. A HFpEF-betegek 2/3-ában a pitvarfibrilláció jelen van és morbiditás, illetve mortalitás növelő tényező (48). HFpEF-ben a pitvarfibrilláció kezelése elengedhetetlen, mert annak megszüntetése esetén a szívelégtelenség szimptómái javulnak (49). Ennek az a magyarázata, hogy HFpEF-ben a bal kamra töltése nagyrészt a késő diasztoléban zajlik és jobban pitvari kontrakciófüggő, mint az egészséges szívben. Emiatt tachycard pitvarfibrillációban a diasztolés idő csökkenése miatt a szimptómák súlyosbodnak. A fentiek alapján, ha HFpEF-ben pitvarfibrilláció jelentkezik, a sinusritmus helyreállítása és megtartása előnyben részesítendő a frekvenciakontrollhoz képest.

\section{A HFpEF echokardiográfiás diagnózisa}

A korábbi ajánlások alapján a szimptómás DD-echokardiográfiás diagnózisa és a súlyosság megítélése sok esetben bizonytalan zónában tartotta a betegeket, ami sokszor a megfelelő kezelést is késleltette. A legújabb ajánlás alapján (50) a HFpEF echokardiográfiás diagnózisa pitvarfibrilláló betegeknél is megállapítható, 


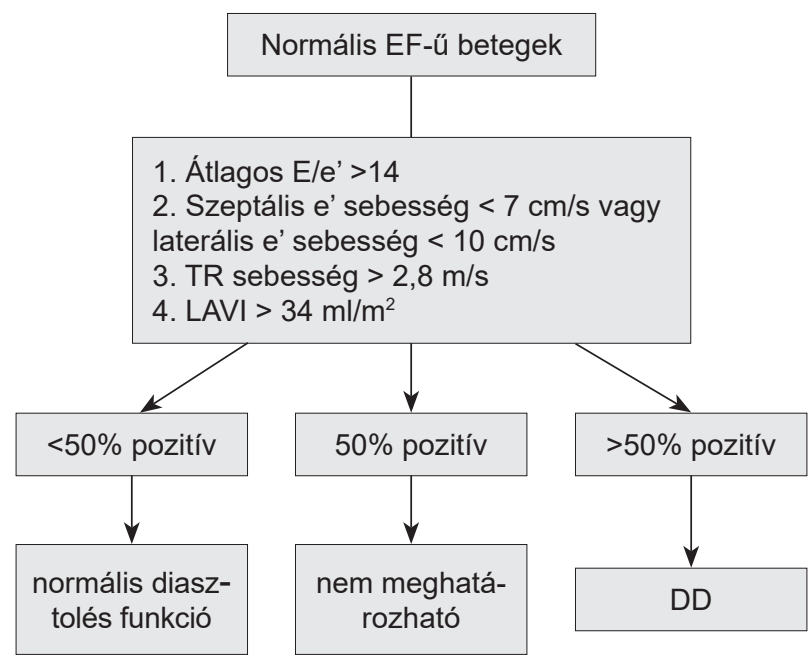

7. ÁBRA. A DD diagnózisa normális EF esetén. TR: tricuspidális regurgitáció (Nagueh SF, et al. nyomán) (50)

mivel a diagnosztikus kritériumok függetlenek a pitvari kontrakció jelenlététöl (7. ábra). Fontos megemlíteni, hogy pitvarfibrilláció alatt mind az E, mind az e' sebesség méréséhez több szívciklust kell átlagolni és hasonló RR-intervallumokat kell használni. Ez gyakran jelentős korlátokat jelent a klinikai gyakorlatban a mérések rutin alkalmazásához. A sebességértékek meghatározhatók 10 egymást követő szívciklusból, de 3 nem egymást követő szívciklus is használható, ha ezek ciklushossz-variabilitása az átlagos szívfrekvencia ciklushosszának 10-20\%-át nem haladja meg.
Ha a betegnél pPF áll fenn és az echokardiográfiás vizsgálatot sinusritmusban végezzük, a $D D$ súlyossága is felállítható (8. ábra).

A klinikumban gyakran elöfordul, hogy a pPF spontán megszűnése vagy gyógyszeres, illetve elektromos kardioverzió után történik TTE-vizsgálat. A kardioverzió után közvetlenül észlelhető bal pitvari stunning jelentősen csökkenti a mitrális beáramlás A-hullámának sebességét, ezért a mitrális E/A hányados alapján látszólagos „pszeudorestriktív” beáramlási mintát látunk. Pár nappal a kardioverzió után megismételt TTE-n látható, hogy a mitrális $A$ sebessége növekszik és az E/A hányados csökken. Ekkor ítélhető meg a DD valódi súlyossága (9. ábra).

\section{Merev balpitvar-szindróma (Stiff left atrial syndrome)}

Az irodalmi adatok alapján ismert, hogy sikeres pitvarfibrilláció abláció után a bal pitvar mérete és volumene szignifikánsan csökken, és nem igazolható a bal pitvar ejekciós és aktív ürítési frakciójának a károsodása (51). Ugyanakkor olyan irodalmi adatok nem állnak a rendelkezésre, amelyek pitvarfibrilláció abláció után a bal pitvar rezervoár- és/vagy konduitfunkcióját vizsgálják. Lehetséges, hogy az abláció után kialakuló bal pitvari heg és fibrózis hátrányosan befolyásolhatja a bal pitvar compliance-ét. Emellett a rádiofrekvenciás katéterabláció károsíthatja a bal pitvar antrális és a

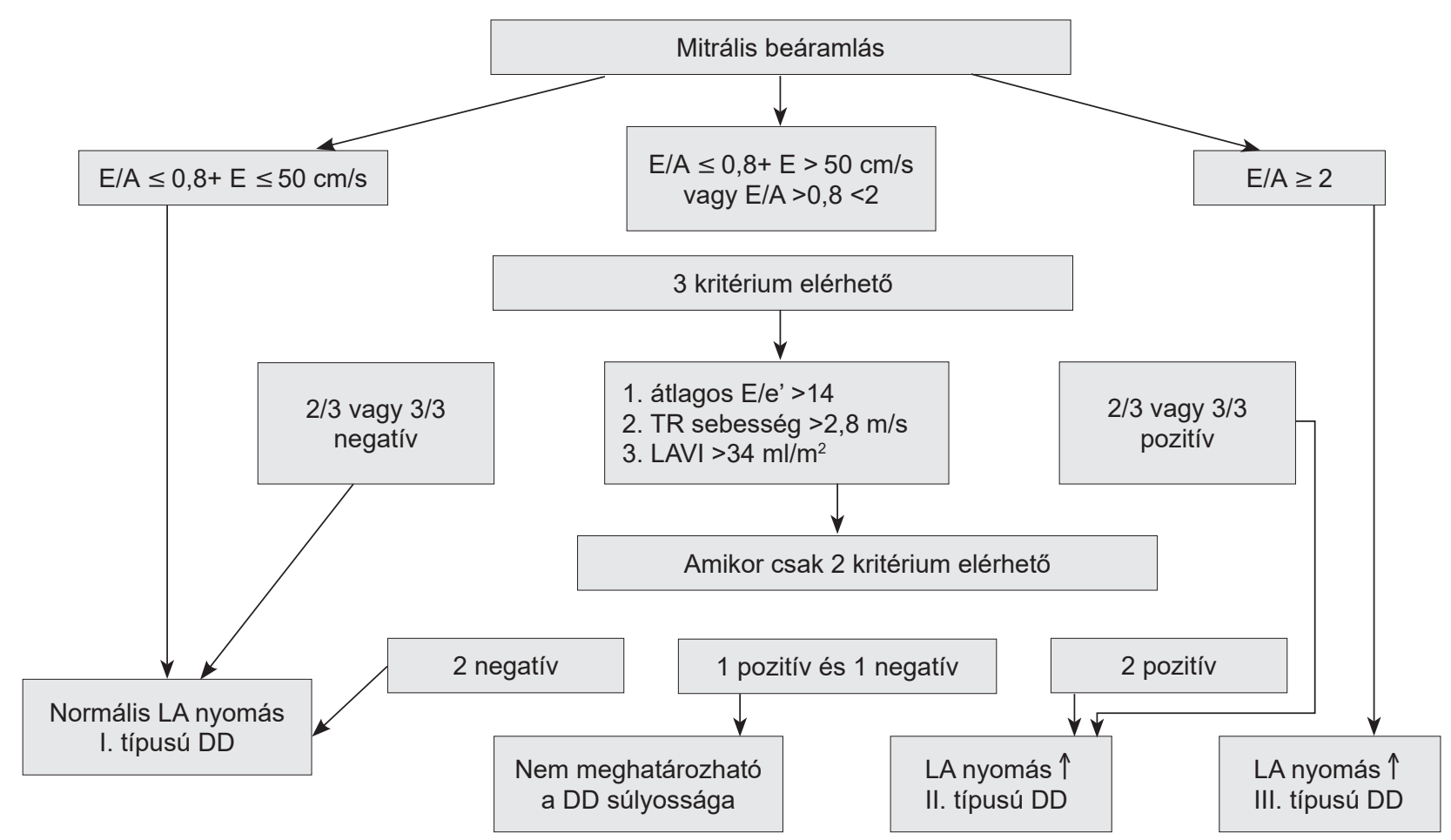

8. ÁBRA. A DD súlyosságának osztályozása megtartott EF esetén sinusritmusban. Érdemes megjegyezni, hogy az emelkedett bal pitvari nyomás becslésére az 1-nél kisebb pulmonalis véna S/D hányados csökkent balkamra-funkciójú betegeknél alkalmazható. LA: bal pitvar (Nagueh SF, et al. alapján módosítva) (50) 

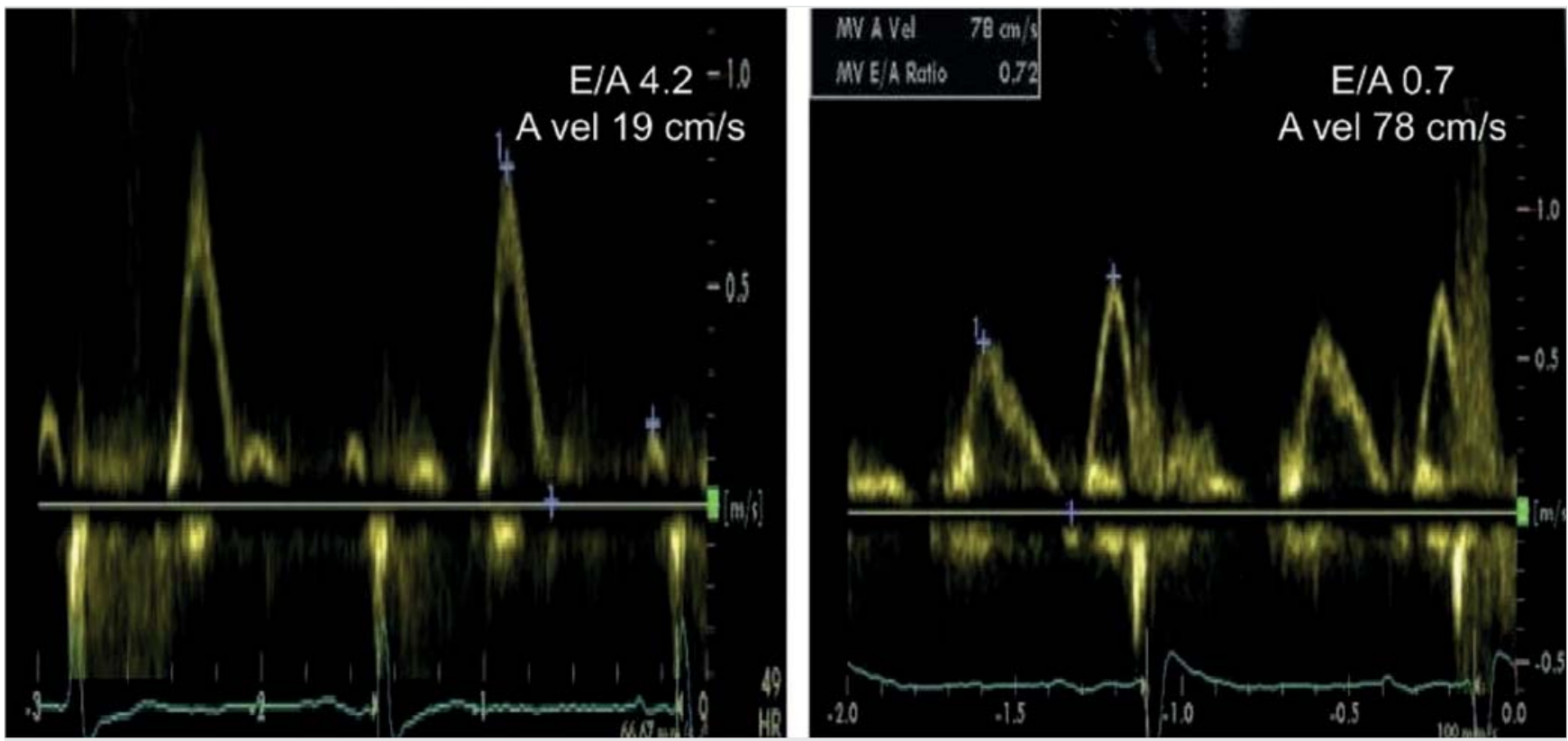

9. ÁBRA. Bal pitvari stunning kardioverzió után. Bal oldal: a kardioverzió napján látszólagos pszeudorestriktív mitrális beáramlás látható. Jobb oldal: 3 nappal később a mitrális A-hullám sebessége jelentősen nő és a mitrális E/A alapján normális bal pitvari nyomás mellett I. fokú DD véleményezhető (Nagueh SF, et al. nyomán) (50)

PV-k oszciális részén elhelyezkedő baroreceptorokat. A csökkent baroreceptor-válaszkészség az arginin vazopresszin megnövekedett felszabadulásán keresztül folyadékretenciót okoz, amely a pulmonalis hipertóniát és az emelkedett bal pitvari nyomást tovább súlyosbítja. Szívsebészeti beavatkozások után korábban már közöltek „stiff left atrial syndrome”-t, amikor szimptómás bal pitvari diszfunkcióhoz asszociált pulmonalis hipertónia alakult ki $(52,53)$. A pitvarfibrilláció rádiofrekvenciás katéterablációja után a merev balpitvarszindróma incidenciája viszonylag ritka (1,4-8\%), de a potenciálisan jelentős szövődmény sokszor nem kerül felismerésre.

A már meglévő jelentős bal pitvari heg, a relatíve kicsi bal pitvari méret $(\leq 45 \mathrm{~mm})$, diabetes mellitus, obstruktív alvási apnoe és a magas bal pitvari nyomás a szindróma kialakulására hajlamosítanak (54). Az ablációt követő 3 hónapon belül szívelégtelenség tünetei és pulmonalis nyomásemelkedés alakul ki. Jellemző, hogy mitrális regurgitáció hiányában a kamrai diasztolé kezdetén emelkedett bal pitvari nyomásra utaló nagy V-hullámok láthatók a pulmonalis kapilláris éknyomás vagy a bal pitvari nyomásgörbén (10. ábra).

\section{A 3 dimenziós transoesophagealis echokardiográfia (3DTEE) szerepe krioabláció (CA) előtt}

A CA során a PV-k elektromos izolációja egy felfújható, a PV szájadékába helyezett ballonkatéterbe áramló dinitrogén-oxid $\left(\mathrm{N}_{2} \mathrm{O}\right)$ következtében létrejövő szöveti hőelvonás (fagyasztás) eredményeként jön létre. A PV-k antrális részén és ostiumában a körkörös folyamatos szöveti lézió létrejöttének alapfeltétele a PV-szájadékot teljesen lezáró felfújt krioballon (11. ábra).

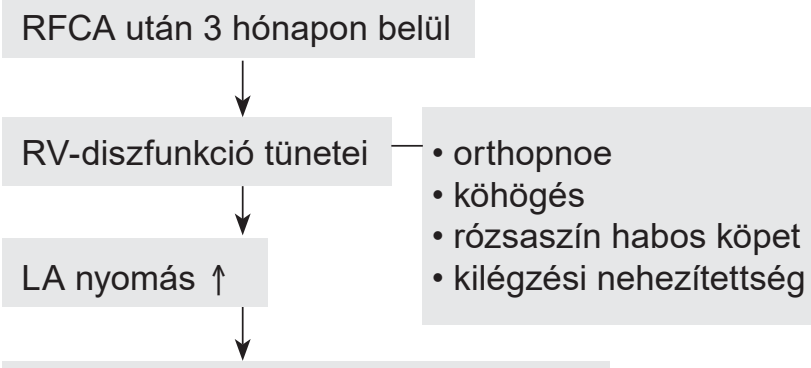

Mély V-hullámok > $10 \mathrm{Hgmm}$ vagy

az LA nyomásgörbe átlagos értéke $\uparrow$

Mitrális elégtelenség kizárása<smiles>[V][V]</smiles>

Átlagos pulmonalis artériás nyomás nyugalomban $\geq 25$ Hgmm, terhelésre $\geq 30$ Hgmm

Pulmonalis stenosis kizárása

Merev balpitvar-szindróma

10. ÁBRA. Stiff left atrial syndrome diagnosztikus algoritmusa. RFCA: rádiofrekvenciás katéterabláció, RV: jobb kamra, LA: bal pitvar (Yang Y, et al. nyomán módosítva) (54) 


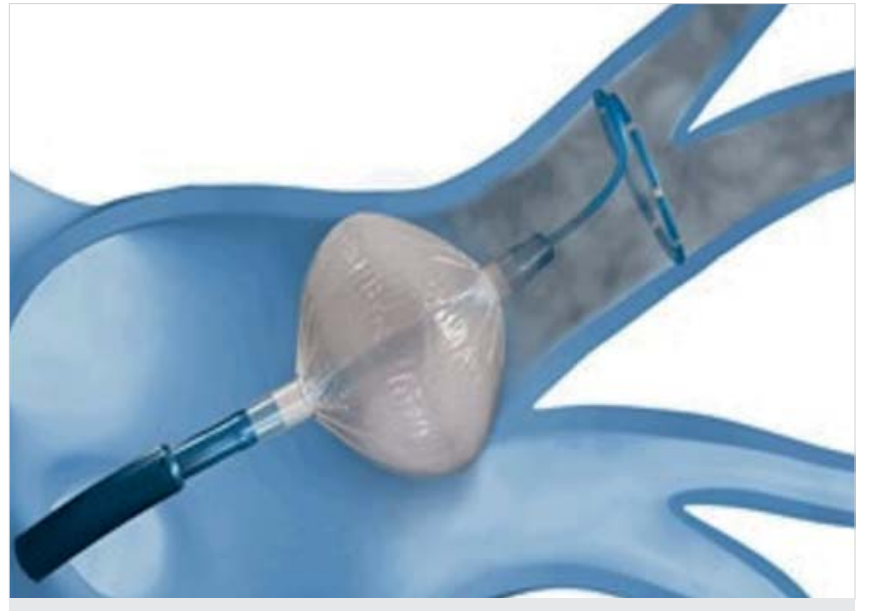

11. ÁBRA. Felfújt krioballon a bal felső PV-ben

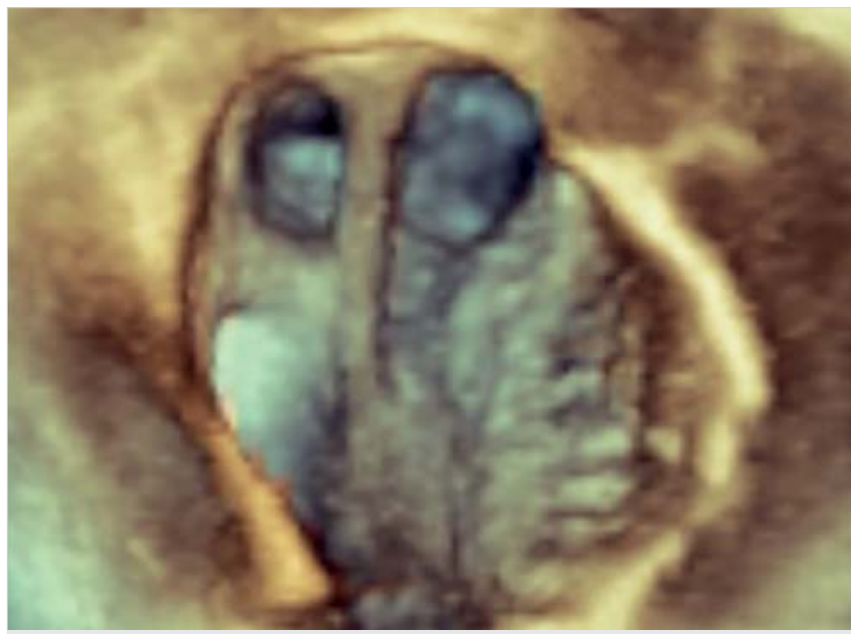

12. ÁBRA. Közös bal oldali szájadék két szeparált PV ostiummal és a bal pitvari fülcse „en face" ábrázolása. Az LLR hosszú és vékony
A tökéletes okklúziót számos anatómiai tényező befolyásolja. A PV-k és azokat körülvevő bal pitvari struktúrák 3DTEE-vel elvégzett preprocedurális analízise több előnyt is hordoz a CT, illetve MR alapján rekonstruált 3 dimenziós képalkotáshoz képest. Azon túl, hogy a preprocedurális anatómiai jellemzők ismerete segíti a beavatkozás tervezését, együlésben kizárható a bal pitvari fülcsethrombus jelenléte is. Emellett a 3DTEE ábrázolási forma jóval kevesebb időt és költséget vesz igénybe, és a CT-képalkotáshoz képest sem a betegnek, sem az egészségügyi személyzetnek nem jelent sugárterhelést (55). Az eddig közölt irodalmi adatok alapján CA előtt a PV-k anatómiai jellemzőinek meghatározása kizárólag $\mathrm{CT}$, illetve MR alapján történt. Ezek alapján több PV anatómiai jellemző prediktív értékét is vizsgálták a CA rövid és hosszabb távú eredményességét illetően: a PV ostium paramétereit (ovalitás index, area) $(56,57,58,59)$, az azonos oldali vénák közötti intervenozus ridge (IVR) $(59,62,63,64)$, valamint a bal oldali PV-k és a fülcse közötti bal laterális ridge (LLR) szélességét $(59,60,61)$, illetve a PV anatómiai variánsok (bal oldali közös PV, szám feletti PV) $(59,60,65)$ jelenlétét.

A 3DTEE-képalkotással „en face” ábrázolhatjuk a PVket és a környező bal pitvari struktúrákat (12-14. ábra). Az így nyert felvételeket analizálva és a T-hullám végén (ekkor legnagyobb a bal pitvari nyomás és a volumen) megfelelő méréseket végezve preprocedurálisan meghatározhatjuk a PV-k anatómiai jellemzőit (15. ábra).

A 12-15. ábra felvételei a Debreceni Egyetem Kardiológiai Tanszékének Echokardiográfiás Laboratóriumából származnak. A felvételeket Philips EPIQ7G echokardiográfiával készítettük. A 3DTEE-vizsgálatok kivitelezéséhez nyújtott aneszteziológiai segítséget $d r$. Zudor Andrásnak hálásan köszönjük.
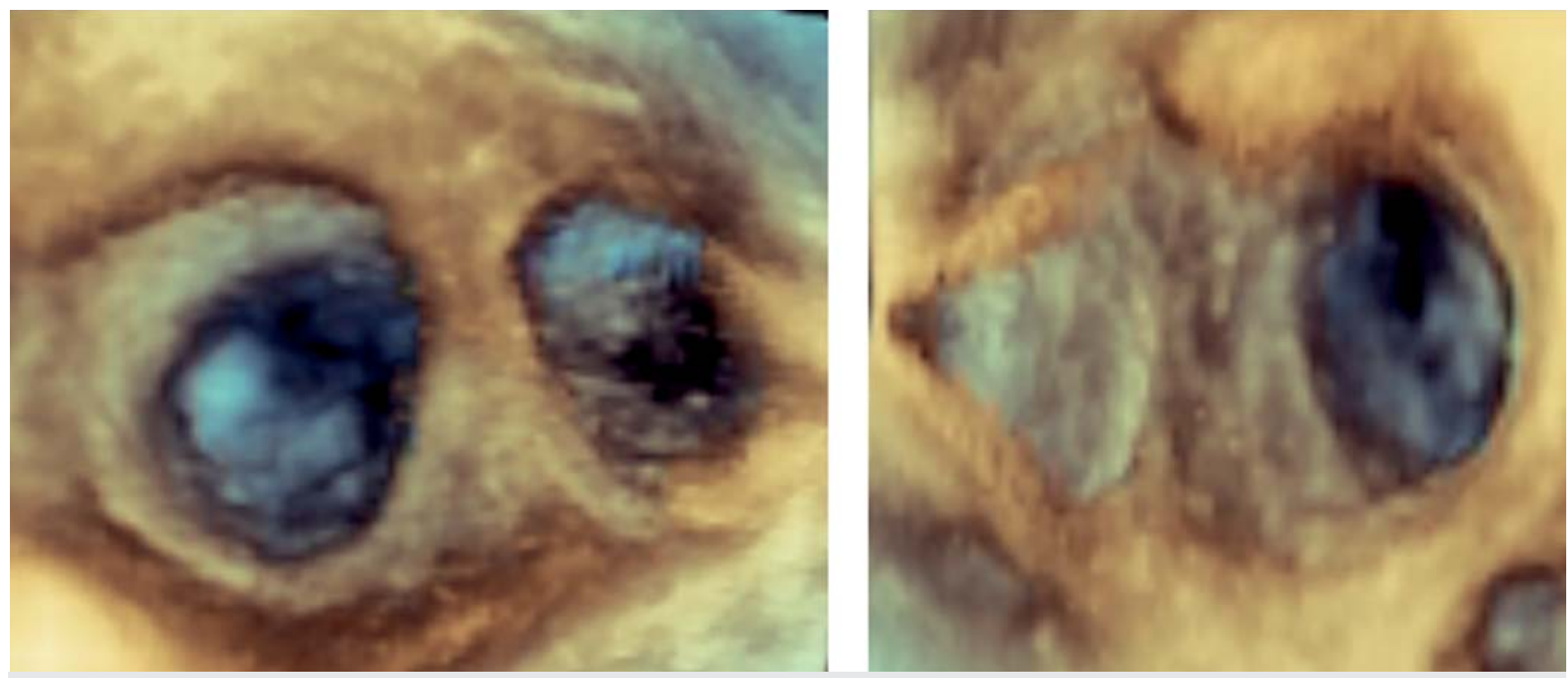

13. ÁBRA. Balra: rövid és széles LLR az „en face” ábrázolt bal pitvari fülcse és a bal felső PV között. Jobbra: szabályos beszájadzású jobb oldali PV-k és az IVR „en face” képe 

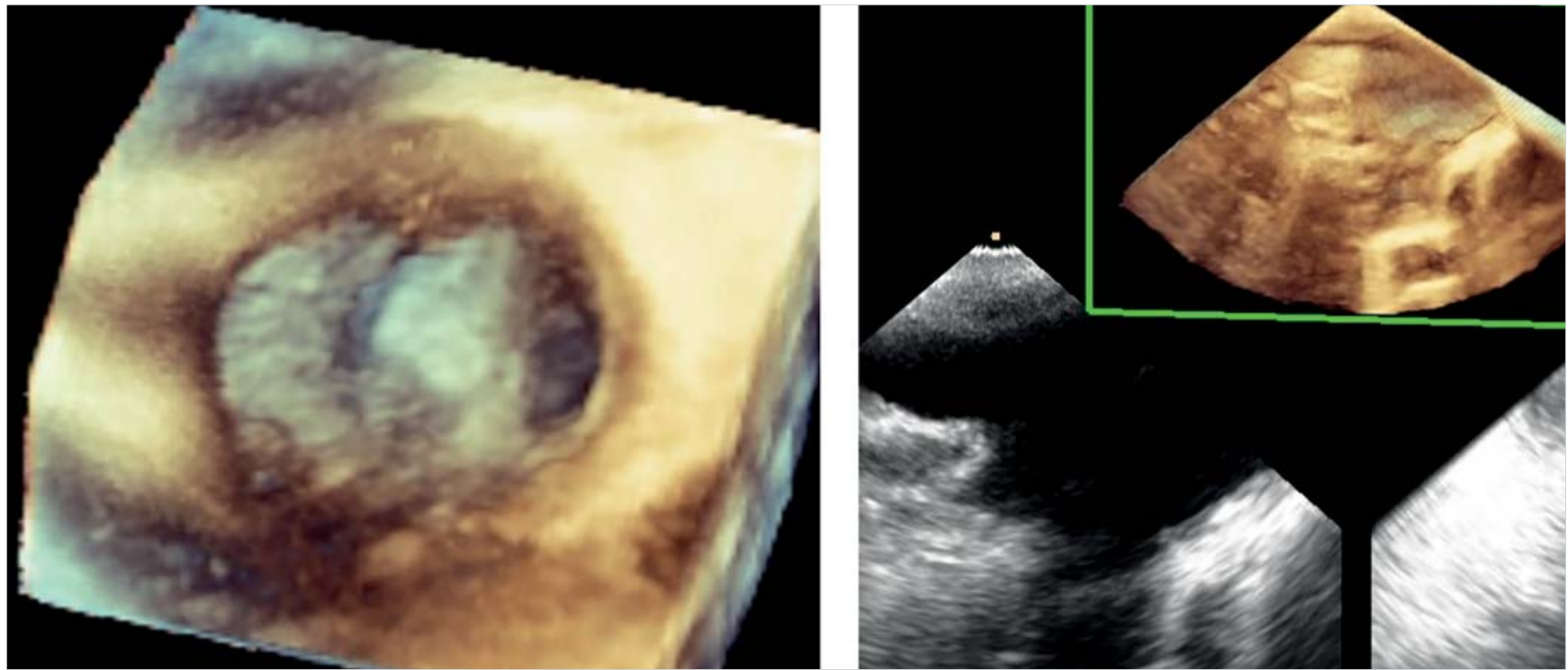

14 ÁBRA. Szám feletti jobb középső PV ábrázolása a bal pitvar üregi nézetéből és hosszmetszetben
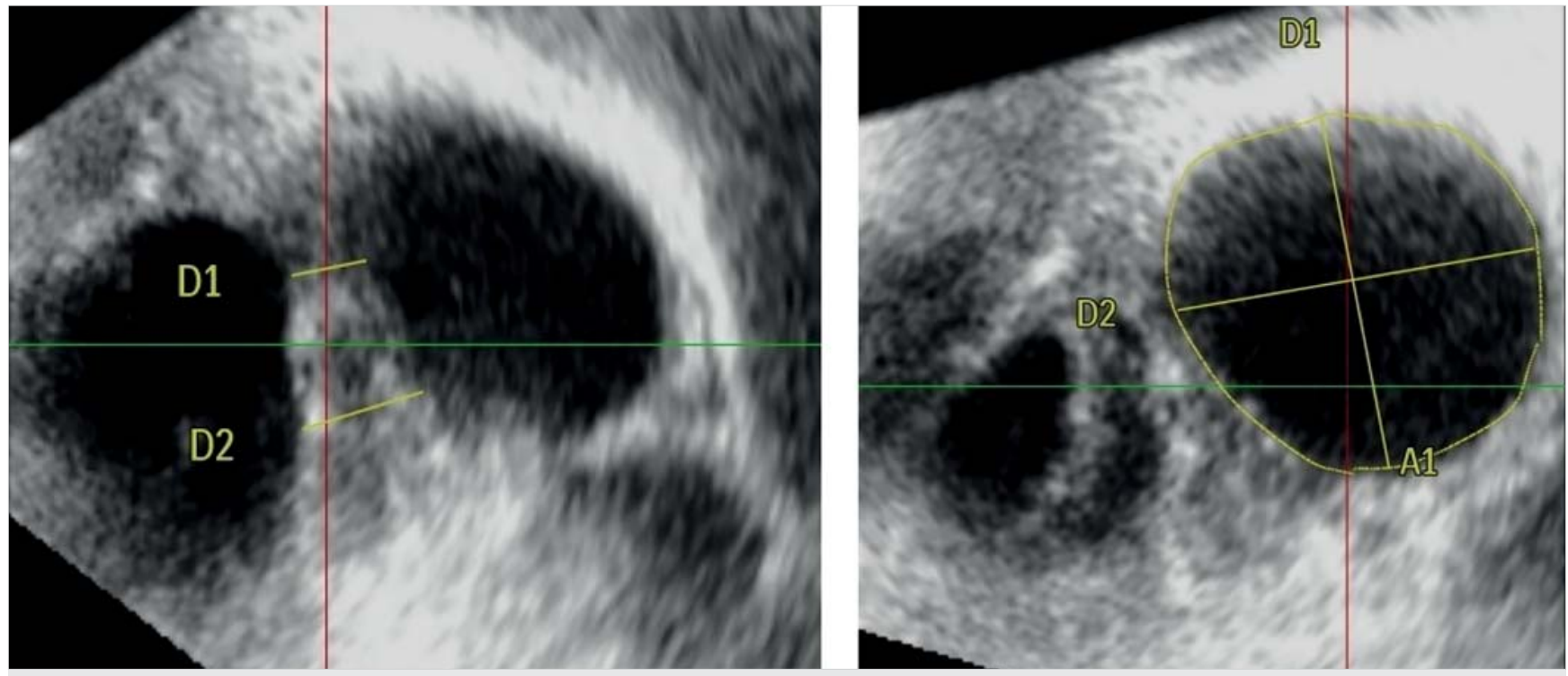

15. ÁBRA. Balra: a jobb IVR vastagságának mérése. Jobbra: az RSPV ostium keresztmetszet egymásra merőleges leghosszabb (D1) és legrövidebb (D2) tengelyének valamint területének (A1) meghatározása. A PV ovalitás index a $2 \times(D 1-D 2) /(D 1+D 2)$ képlettel meghatározott arányszám

\section{Következtetések}

PVI-re legalkalmasabb betegek kiválasztására a 2 dimenziós TTE- és TEE-vizsgálatok alapvető fontosságúak. A megtartott balkamra-funkciójú, paroxizmális és egy évnél nem hosszabb perzisztáló pitvarfibrilláló betegeknél fontos preprocedurálisan meghatározni a bal pitvar strukturális és funkcionális remodellációjának mértékét, mert ezek ismerete prediktív értékủ a későbbi kardiovaszkuláris események és a PVI sikeressége szempontjából. A bal pitvari strain meghatározása a közeljövőben a napi klinikai rutin részévé válhat. $A$ bal pitvari funkció jellemzése mellett a pitvarfibrilláció előfordulásának a prediktora és a tromboembóliás rizikó meghatározásában is szerepe van. A bal pitvari fülcsethrombus kizárásához szükséges TEE-vizsgálatot több klinikai tényező egyénre szabott mérlegelése után érdemes indikálni. A PVI során az ICE alkalmazása javítja a bal pitvari fülcsethrombus diagnózisának pontosságát. Ha a betegnél CA-t tervezünk, akkor a preprocedurálisan elvégzett 3DTEE-vizsgálattal a fülcsethrombus kizárása mellett a PV-k anatómiai jellemzőit is meghatározhatjuk, amelynek ismerete a beavatkozás tervezését és a CA sikerességét egyaránt befolyásolhatja. 


\section{Köszönetnyilvánítás}

Apublikációelkészítéséta GINOP-2.3.2-15-2016-00043 számú, „Szív- és érkutatási kiválóságközpont (IRONHEART)" címü projekt támogatta. A projekt az Európai Unió támogatásával, az Európai Regionális Fejlesztési Alap társfinanszírozásával valósult meg.

\section{Irodalom}

1. Lang RM, Badano LP, Mor-Avi V, et al. Recommendations for cardiac chamber quantification by echocardiography in adults: an update from the American Society of Echocardiography and the European Association of Cardiovascular Imaging. Eur Heart J Cardiovasc Imaging 2015; 16(3): 233-70. doi: 10.1093/ehjci/jev014.

2. Barnes ME, Miyasaka Y, Seward JB, et al. Left atrial volume in the prediction of first ischemic stroke in an elderly cohort without atrial fibrillation. Mayo Clin Proc 2004; 79: 1008-1014. doi: 10.4065/79.8.1008

3. Takemoto Y, Barnes ME, Seward JB, et al. Usefulness of left atrial volume in predicting first congestive heart failure in patients $>$ or $=65$ years of age with well-preserved left ventricular systolic function. Am J Cardiol 2005; 96: 832-836. doi: 10.1016/j.amjcard.2005.05.031 4. Patel DA, Lavie CJ, Milani RV, Ventura HO. Left atrial volume index predictive of mortality independent of left ventricular geometry in a large clinical cohort with preserved ejection fraction. Mayo Clin Proc 2011; 86: 730-737. doi: 10.4065/mcp.2010.0682

5. Tsang TS, Abhayaratna WP, Barnes ME, et al. Prediction of cardiovascular outcomes with left atrial size: is volume superior to area or diameter? J Am Coll Cardiol 2006; 47:1018-1023. doi: 10.1016/j. jacc.2005.08.077

6. Lester SJ, Ryan EW, Schiller NB, Foster E. Best method in clinical practice and in research studies to determine left atrial size. Am J Cardiol 1999; 84: 829-832. doi: 10.1016/S0002-9149(99)00446-4 7. Ujino K, Barnes ME, Cha SS, et al. Two-dimensional echocardiographic methods for assessment of left atrial volume. Am J Cardiol 2006; 98: 1185-1188. doi: 10.1016/j.amjcard.2006.05.040

8. Badano LP, Pezzutto N, Marinigh R, et al. How many patients would be misclassified using $\mathrm{M}$-mode and two-dimensional estima tes of left atrial size instead of left atrial volume? A three-dimensional echocardiographic study. J Cardiovasc Med 2008; 9: 476-484. doi: 10.2459/JCM.0b013e3282f194f0

9. Anwar AM, Soliman OI, Geleijnse ML, et al. Assessment of left atrial volume and function by real-time three-dimensional echocardiography. Int J Cardiol 2008; 123: 155-161. doi: 10.1016/j.ijcard.2006.12.017

10. Mor-Avi V, Yodwut C, Jenkins C, et al. Real-time 3D echocardiographic quantification of left atrial volume: multicenter study for validation with CMR. JACC Cardiovasc Imaging 2012; 5:769-777. doi: 10.1016/j.jcmg.2012.05.011

11. Suh IW, Song JM, Lee EY, et al. Left atrial volume measured by real-time 3-dimensional echocardiography predicts clinical outco mes in patients with severe left ventricular dysfunction and in sinus rhythm. J Am Soc Echocardiogr 2008; 21: 439-445. doi: 10.1016/j. echo.2007.09.002

12. Maddukuri PV, Vieira ML, DeCastro $S$, et al. What is the best approach for the assessment of left atrial size? Comparison of various unidimensional and two-dimensional parameters with three-dimensional echocardiographically determined left atrial volume. J Am Soc Echocardiogr 2006; 19:1026-1032. doi: 10.1016/j. echo.2006.03.011

13. Pathak R, Lau DH, Mahajan R, Sanders P. Structural and func tional remodeling of the left atrium: clinical and therapeutic implications for atrial fibrillation. J Atr Fibrillation 2013; 6(4): 986. doi: 10.4022/jafib.986.

14. D’Ascenzi F,Anselmi F, Focardi M, et al. Atrial enlargement in the athlete's heart: assessment of atrial function may help distinguish adaptive from pathologic remodeling. J Am Soc Echocardiogr 2018; 31: 148-57. doi: 10.1016/j.echo.2017.11.009

15. Casaclang-Verzosa G, Gersh BJ, Tsang TSM. Structural and functional remodeling of the left atrium: clinical and therapeutic implications for atrial fibrillation. J Am Coll Cardiol 2008; 51: 1-11. doi: 10.1016/j.jacc.2007.09.026

16. Pontecorboli G, Figueras i Ventura RM, Carlosena A, et al. Use of delayed-enhancement magnetic resonance imaging for fibrosis detection in the atria: a review. Europace 2017; 19: 180-189. doi:10.1093/europace/euw053.

17. Akoum N, Daccarett M, McGann C,et al. Atrial fibrosis helps select the appropriate patient and strategy in catheter ablation of atrial fibrillation: a DE-MRI guided approach. J Cardiovasc Electrophysio 2011; 22: 16-22. doi: 10.1111/j.1540-8167.2010.01876.x

18. Kaminski M, Steel K, Jerosch-Herold M, et al. Strong cardiovascular prognostic implication of quantitative left atrial contractile function assessed by cardiac magnetic resonance imaging in patients with chronic hypertension. J Cardiovasc Magn Reson 2011; 13: 42. doi: 10.1186/1532-429X-13-42

19. Wang M, Yip GW, Wang AY, et al. Peak early diastolic mitral annulus velocity by tissue Doppler imaging adds independent and incremental prognostic value. J Am Coll Cardiol 2003; 41: 820-826. doi: 10.1016/S0735-1097(02)02921-2

20. Blume GG, Mcleod CJ, Barnes ME, et al. Left atrial function:physiology, assessment, and clinical implications.Eur J Echocardiogr 2011; 12: 421-430. doi: 10.1093/ejechocard/jeq175

21. Lester SJ, Ryan EW, Schiller NB, Foster E. Best method in clinical practice and in research studies to determine left atrial size. Am J Cardiol 1999; 84: 829-32. doi: 10.1016/S0002-9149(99)00446-4 22. Rodevan O, Bjornerheim $R$, Ljosland $M$, et al. Left atrial volumes assessed by three- and two-dimensional echocardiography compared to MRI estimates. Int J Card Imaging 1999; 15: 397-410. doi: 10.1023/A:100627651

23. Galli E, Fournet M, Chabanne $C$,et al. Prognostic value of left atrial reservoir function in patients with severe aortic stenosis: a 2D speckle-tracking echocardiographic study. Eur Heart J Cardiovasc Imaging 2016; 17: 533-541. doi: 10.1093/ehjci/jev230.

24. Sarvari SI, Haugaa KH, Stokke TM, et al. Strain echocardiographic assessment of left atrial function predicts recurrence of atrial fibrillation. Eur Heart J Cardiovasc Imaging 2016; 17: 660-667. doi: 10.1093/ehjci/jev185.

25. Donal E, Behagel A, Feneon D. Value of left atrial strain: a highly promising field of investigation. Eur Heart J Cardiovasc Imaging 2015; 16: 356-357. doi: 10.1093/ehjci/jeu230.

26. Donal E, Lip GY, Galderisi M, et al. EACVI/EHRA Expert Consensus Document on the role of multimodality imaging for the evaluation of patients with atrial fibrillation. Eur Heart J Cardiovasc Imaging 2016; 17: 355-383. doi: 10.1093/ehjci/jev354.

27. Motoki H, Negishi K, Kusunose K, et al. Global left atrial strain in the prediction of sinus rhythm maintenance after catheter ablation for atrial fibrillation. J Am Soc Echocardiogr 2014; 27: 1184-1192. doi:10.1016/j.echo.2014.08.017.

28. Leung M, van Rosendael PJ, Abou R, et al. Left atrial function to identify patients with atrial fibrillation at high risk of stroke: new insights from a large registry. Eur Heart J 2018; 39(16): 1416-1425. doi: 10.1093/eurheartj/ehx736.

29. Singh A, Addetia K, Maffessanti F,et al. LA strain for categorization of LV diastolic dysfunction. JACC Cardiovasc Imaging 2017; 10 : 735-743. doi: 10.1016/j.jcmg.2016.08.014

30. Santos AB, Roca GQ, Claggett B, et al. Prognostic relevance of left atrial dysfunction in heart failure with preserved ejection fraction. Circ Heart Fail 2016; 9: e002763. doi: 10.1161/CIRCHEARTFAILURE.115.002763.

31. Pathan F, D'Elia N, Nolan MT, et al. Normal ranges of left atrial strain by speckle-tracking echocardiography: a systematic review and meta-analysis. J Am Soc Echocardiogr 2017; 30: 59-70.e8. doi: 10.1016/j.echo.2016.09.007.

32. Scherr D, Dalal D, Chilukuri K, et al. Incidence and predictors of left atrial thrombus prior to catheter ablation of atrial fibrillation. $J$ Cardiovasc Electrophysiol 2009; 20: 379-384. doi: 10.1111/j.15408167.2008.01336.x

33. Calkins H, Kuck KH, Cappato $R$, et al. 2012 HRS/EHRA/ECAS expert consensus statement on catheter and surgical ablation of at- 
rial fibrillation: recommendations for patient selection, procedural techniques, patient management and follow-up, definitions, endpoints, and research trial design: a report of the Heart Rhythm Society (HRS) Task Force on Catheter and Surgical Ablation of Atria Fibrillation. Heart Rhythm 2012; 9: 632-696. e21. doi: 10.1016/j.hrthm.2011.12.016

34. The Stroke Prevention in Atrial Fibrillation Investigators Committee on Echocardiography. Transesophageal echocardiographic correlates of thromboembolism in high-risk patients with nonvalvular atrial fibrillation. Ann Intern Med 1998; 128: 639-647.

35. Zabalgoitia M, Halperin JL, Pearce LA, et al. Transesophageal echocardiographic correlates of clinical risk of thromboembolism in nonvalvular atrial fibrillation: Stroke Prevention in Atrial Fibrillation III Investigators. J Am Coll Cardiol 1998; 31: 1622-1666. doi: 10.1016/ S0735-1097(98)00146-6

36. Agmon Y, Khandheria BK, Meissner I, et al. Are left atrial appendage flow velocities adequate surrogates of global left atrial function? A population-based transthoracic and transesophageal echocardiographic study. J Am Soc Echocardiogr 2002; 15(5): 433-40. doi: 10.1067/mje.2002.116826

37. Bollmann A, Binias K, Grothues F, et al. Left atrial appendage flow in nonrheumatic atrial fibrillation: relationship with pulmonary venous flow and ECG fibrillatory wave amplitude. Chest 2001; 119 : 485-492. doi: 10.1378/chest.119.2.485

38. Tsiaousis G, Beidekos D, Theodosis-Georgilas A. The E/Em ratio in the prediction of left atrial appendage function. Eur J Echocardiogr 2008; (suppl 1): S153.

39. Sriram CS, Banchs JE, Moukabary T, et al. Detection of left atrial thrombus by intracardiac echocardiography in patients undergoing ablation of atrial fibrillation. J Interv Card Electrophysiol 2015; 43(3): 227-36. doi: 10.1007/s10840-015-0008-2.

40. Baran J, Zaborska B, Piotrowski R, et al. Intracardiac echocardiography for verification for left atrial appendage thrombus presence detected by transesophageal echocardiography: the ActionICE II study. Clin Cardiol 2017; 40(7): 450-454.doi: 10.1002/clc.22675. 41. Persson $\mathrm{H}$, Lonn $\mathrm{E}$, Edner $\mathrm{M}$, et al. Diastolic dysfunction in heart failure with preserved systolic function: need for objective evidence:results from the CHARM Echocardiographic Substudy-CHARMES. J Am Coll Cardiol 2007; 49: 687-94. doi: 10.1016/j.jacc.2006.08.062 42. Tsang TS, Gersh BJ, Appleton CP, et al. Left ventricular diastolic dysfunction as a predictor of the first diagnosed nonvalvular atrial fibrillation in 840 elderly men and women. J Am Coll Cardiol 2002; 40: 1636-1644. doi: 10.1016/S0735-1097(02)02373-2

43. Reant $P$, Lafitte $S$, Jaïs $P$, et al. Reverse remodeling of the left cardiac chambers after catheter ablation after 1 year in a series of patients with isolated atrial fibrillation. Circulation 2005; 112: 28962903. doi: 10.1161/CIRCULATIONAHA.104.523928

44. Reant $P$, Lafitte $S$, Bougteb $H$, et al. Effect of catheter ablation for isolated paroxysmal atrial fibrillation on longitudinal and circumferential left ventricular systolic function. Am J Cardiol 2009; 103: 232-237. doi: 10.1016/j.amjcard.2008.08.070

45. Donal E, Ollivier R, Veillard D, et al. Left atrial function assessed by trans-thoracic echocardiography in patients treated by ablation for a lone paroxysmal atrial fibrillation. Eur J Echocardiogr 2010; 11: 845-852. doi: 10.1093/ejechocard/jeq074

46. Kosiuk J, Van Belle Y, Bode $\mathrm{K}$, et al. Left ventricular diastolic dysfunction in atrial fibrillation: predictors and relation with symptom severity. J Cardiovasc Electrophysiol 2012; 23: 1073-1077. doi: 10.1111/j.1540-8167.2012.02368.x

47. Mentz RJ, Kelly JP, von Lueder TG, et al. Noncardiac comorbidities in heart failure with reduced versus preserved ejection fraction. J Am Coll Cardiol 2014; 64(21): 2281-93.doi: 10.1016/j. jacc.2014.08.036

48. Zakeri R, Chamberlain AM, Roger VL, Redfield MM. Temporal relationship and prognostic significance of atrial fibrillation in heart failure patients with preserved ejection fraction: a community-based study. Circulation 2013; 128 (10): 1085-93. doi: 10.1161/CIRCULATIONAHA.113.001475.

49. Yancy CW, Jessup M, Bozkurt B, et al. 2016 ACC/AHA/HFSA
Focused Update on New Pharmacological Therapy for Heart Failure: An Update of the 2013 ACCF/AHA Guideline for the Management of Heart Failure: A Report of the American College of Cardiology/ American Heart Association Task Force on Clinical Practice Guidelines and the Heart Failure Society of America. J Am Coll Cardiol 2016; 68(13): 1476-1488. doi: 10.1016/j.jacc.2016.05.011.

50. Nagueh SF, Smiseth OA, Appleton CP, et al. Recommendations for the evaluation of left ventricular diastolic function by echocardiography: an update from the American Society of Echocardiography and the European Association of Cardiovascular Imaging. J Am Soc Echocardiogr 2016; 29(4): 277-314. doi: 10.1016/j. echo.2016.01.011.

51. Jeevanantham V, Ntim W, Navaneethan SD, et al.Meta-analysis of the effect of radiofrequency catheter ablation of left atrial size, volumes and function in patients with atrial fibrillation. Am J Cardiol 2010; 105: 1317-1326. doi: 10.1016/j.amjcard.2009.12.046

52. Pilote L, Hunter I, Marpole D, Sniderman A. Stiff left atrial syndrome. Can J Cardiol 1988; 4: 255-257.

53. Mehta S, Charbonneau F, Fitchett DH, et al. The clinical consequences of a stiff left atrium. Am Heart J 1991; 122: 1184-1191.

54. Yang $Y$, Liu $Q, W u$ Z, et al. Stiff Left Atrial Syndrome: A complication undergoing radiofrequency catheter ablation for atrial fibrillation. J Cardiovasc Electrophysiol 2016; 27(7): 884-9. doi: 10.1111/jce.12966. 55. Ottaviano L, Chierchia GB, Bregasi A, et al. Cryoballoon ablation for atrial fibrillation guided by real-time three-dimensional transoesophageal echocardiography: a feasibility study. Europace 2013; 15 : 944-950. doi: 10.1093/europace/eus431

56. Güler E, Güler GB, Demir GG, et al. Effect of pulmonary vein anatomy and pulmonary vein diameters on outcome of cryoballoon catheter ablation for atrial fibrillation. Pacing Clin Electrophysiol PACE 2015; 38(8): 989-996. doi: 10.1111/pace.12660

57. Baran J, Piotrowski R, Sikorska A, et al. Impact of pulmonary vein ostia anatomy on efficacy of cryoballoon a blation for atrial fibrillation. HBJ 2016; 1: 65-70. doi: https://doi.org/10.24255/hbj/68162 58. Sorgente A, Chierchia GB, de Asmundis C, et al. Pulmonary vein ostium shape and orientation as possible predictors of occlusion in patients with drug-refractory paroxysmal atrial fibrillation undergoing cryoballoon ablation. Europace 2011; 13: 205-212. doi: 10.1093/europace/euq388

59. Knecht S, Kühne M, Altmann D, et al. Anatomical predictors for acute and mid-term success of cryoballoon ablation of atrial fibrillation using the $28 \mathrm{~mm}$ balloon. J Cardiovasc Electrophysiol 2013; 24 : 132-138. doi: 10.1111/jce.12003

60. Cabrera JA,Ho SY, Climent V, Sanchez-Quintana D. The architecture of the left lateral atrial wall: a particular anatomic region with implications for ablation of atrial fibrillation. Eur Heart J 2008; 29: 356-362. doi: 10.1093/eurheartj/ehm606

61. Mansour M, Refaat M, Heist EK, et al. Three-dimensional anatomy of the left atrium by magnetic resonance angiography:implications for catheter ablation for atrial fibrillation. J Cardiovasc Electrophysiol 2006; 17: 719-723. 10.1111/j.1540-8167.2006.00491.x

62. Cabrera JA,Ho SY,Climent V, et al. Morphological evidence of muscular connections between contiguous pulmonary venous orifices: relevance of the interpulmonary isthmus for catheter ablation in atrial fibrillation. Heart Rhythm 2009; 6: 1192-1198. doi: 10.1016/j. hrthm.2009.04.016

63. McLellan JAA, Ling L, Ruggiero D, et al. Pulmonary vein isolation:The impact of pulmonary venous anatomy on long term outcome of catheter ablation for paroxysmal atrial fibrillation. Heart Rhythm 2014; 11: 549-556. 10.1016/j.hrthm.2013.12.025

64. Chun K-RJ, Schmidt B, Metzner A, et al. The "single big cryoballoon" technique for acute pulmonary vein isolation in patients with paroxysmal atrial fibrillation: A prospective observational single centre study. Eur Heart J 2009; 30: 699-709. 10.1093/eurheartj/ ehn570

65. Kubala M, Hermida JS, Nadji G, et al. Normal pulmonary veins anatomy is associated with better AF-free survival after cryoablation as compared to atypical anatomy with common left pulmonary vein. PACE 2011; 34: 837-843. 10.1111/j.1540-8159.2011.03070.x 